\title{
ASPEK HUKUM PIDANA DALAM KAITANNYA DENGAN PERIZINAN DI BIDANG PERTAMBANGAN
}

\author{
Oheo K.Haris \\ oheokh73@yahoo.co.id \\ Fakultas Hukum Universitas Haluoleo Kendari
}

\begin{abstract}
Formulation of maladministration is confounding between a fault, an official responsibility or a personal responsibility. The definition of maladministration in the criminal provisions on the Act 4 of 2009, the formulation of Article 165 does not specify fault elements as well as the intent and dolus and culpa relating to criminal liability. In addition, the criminal provisions on the Act No. 4 of 2009 has not memprekripsikan of malversation as a whole, only contains a clause of Article 165. In many cases related to the regional head of mining permits in some areas, so many overlapping permits caused by maladministration authoritie.
\end{abstract}

Keywords: maladministration, responsibilities, permissions.

\begin{abstract}
Abstrak
Rumusan maladministrasi masih mencampuradukan antara kesalahan dan atau tanggung jawab jabatan dengan kesalahan dan atau tanggung jawa pribadi. definisi maladministrasi. Terkait dengan ketentuan pidana UU No.4 Tahun 2009, formulasi pasal 165 tidak menentukan unsur kesalahan serta kesengajaan dan kelapaan dolus dan culpa berkaitan dengan pertanggungjawaban pidana. Di samping itu, ketentuan pidana dalam UU No. 4 Tahun 2009 belum memprekripsikan tentang kejahatan jabatan secara utuh, hanya memuat satu pasal yakni pasal 165. Padahal dalam berbagai kasus kepala daerah terkait dengan izin pertambangan di beberapa daerah, begitu banyaknya tumpang tindih izin yang disebabkan oleh maladministrasi pejabat berwenang.
\end{abstract}

Kata Kunci : maladministrasi, tanggung jawab, izin. 


\section{Pendahuluan}

Kekayaan alam dan hasil bumi Indonesia adalah merupakan suatu anugerah dari Tuhan Yang Maha Esa, demikian pula hasil tambang. Namun dalam hal pengelolaan hasil tambang tersebut dapat saja menuai masalah khususnya terkait dengan izin pertambangan yang dapat saja berimplikasi hukum. Pada tulisan ini dikemukakan kewenangan diskresi pemerintah yang secara filosofi bahwa sesungguhnya esensi daripada perizinan itu, khususnya dibidang pertambangan adalah merupakan suatu arah cita-cita suatu masyarakat adil makmur yang sekaligus merupakan bagian dari memajukan kesejahteraan rakyat dan serta meningkatkan perekonomian bangsa dan negara Indonesia. Hal tersebut sebagaimana telah diatur dalam Pembukaan Undang-undang Dasar 1945 serta Pasal 33 Undang-undang Dasar 1945 setelah amandemen. ${ }^{1}$ Namun demikian, pemberian izin oleh Pemerintah Provinsi atau Bupati dapat dipandang sebagai kebebasan bertindak atau lazim disebut discretion ${ }^{2}$ atau diskresi yang tentunya mempunyai parameter.

Kebebasan bertindak pemerintah (discretionary power) khususnya pada izin di bidang pertambangan oleh pemerintah yang mengarah pada penyalahgunaan wewenang dan tindak pidana korupsi telah menjadi bagian perhatian khusus di Indonesia. Hal ini disebabkan oleh maraknya maladministrasi atau ketidaksedian hukum administrasi. Tanpa hukum administrasi tidak mungkin asas negara hukum dapat diwujudkan. Demikian pula dengan isu Good Governance tidak mungkin hal tersebut dapat terwujud tanpa hukum administrasi. ${ }^{3}$

Fungsi hukum administrasi tidak bisa diabaikan dalam kaitannya dengan tindak pidana korupsi, baik dari segi preventif maupun represif. Instrument hukum yang utama untuk mewujudkan pemerintah yang bersih adalah hukum administrasi. demikian peran hukum administrasilah yang diharapkan untuk mencegah korupsi, karena korupsi berkaitan dengan penggunaan wewenang. Oleh karena itu pemahaman akan hukum administrasi dan pembangunan hukum administrasi mutlak diperlukan. Kenyataan menunjukkan saat ini masih sangat minim dan banyak yang salah mengartikan hukum administrasi. Demikian juga pembangunan hukum administrasi nampaknya tidak sistematis dan tidak fundamental. Penanganan tindak pidana korupsi masih fokus pada aspek hukum pidana, dan sedikit sekali perhatian terhadap hukum administrasi. $^{4}$

Namun demikian, dalam pelaksanaan pemberian izin oleh pemerintah dapat dipandang sebagai wujud dalam rangka mewujudkan kesejahteraan masyarakat sebesar-besarnya dan meningkatkan perekenomian negara sebanyak-banyaknya, sehingga bangsa Indonesia dapat sejajar dengan negara-negara lain. Dari pernyataan tersebut diatas, dapat ditarik suatu isu

1 Lembaran Negara Undang-undang Dasar 1945 Republik Indonesia.

2 Martin Basiang, The Contemporary Law Dictionary, First Edition, Red and White Publishing, 2009, h.145. Discretion (Ing), Kebijaksanaan, hikmat, suatu keputusan pimpinan atas dasar dan hati nurani: wijsheid, verstand (Bld). Discretionaire Bevoegheid (Bld), kewenangan yang dilaksanakan hakim tidak secara kaku dan formal yuridis tetapi dengan pertimbangan yang bijaksana dan berkeadilan; Discretionary Competence (Ing). * De ruimte die ter discretie van de rechter staat, vrije beslissingsruimte, niet allen rechmatig maar ook doelmatig.

3 Philipus M.Hadjon, Paulus Effendie Lotulung, H.M. Laica Marzuki, Tatiek Sri Djatmiati, I Gusti Ngurah Wairocana, Hukum Administrasi dan Good Governance, Jakarta: Universitas Trisakti, 2010, h.25.

4 Philipus M.Hadjon, Tatiek Sri Djatmiati, G.H. Addink, J.B.J.M. Ten Berge, Hukum Administrasi Dan Tindak Pidana Korupsi, Yogyakarta: Gadjah Mada University Press, 2011, h.30 
hukum yang pantas untuk ditelaah yakni apakah bentuk tanggung jawab tindak pidana dibidang pertambangan dan konsep apa yang berfungsi sebagai penopang diskresi pemerintah.

\section{Hakikat Izin Pertambangan (Discretionary Power) Oleh Pemerintah}

Hakikat dan kepastian hukum dalam menentukan adanya inisiatif suatu pemerintah adalah memastikan dalam tindakan tersebut adanya suatu prinsip legalitas hukum. Tentunya pelaksanaan tersebut terdapat suatu akibat yang secara makna mengarah pada suatu kepastian hukum. Dengan demikian bahwa tindakan kebebasan pemerintah tersebut sangat dimungkinkan oleh hukum dan memenuhi unsur dari diskresi pemerintah atau Ermessen. ${ }^{5}$

Dalam penjelasan Philipus M.Hadjon menegaskan bahwa diskresi dalam kepustakaan hukum administrasi istilah yang sering digunakan adalah kekuasaan bebas. ${ }^{6}$ Dalam praktek sering terdengar istilah kebijakan atau kebijaksanaan. Sebagai perbandingan diketengahkan istilah yang digunakan dalam berbagai sistem hukum administrasi. Dari paparan tersebut istilah diskresi selayaknya dipopulerkan sesuai dengan Hakikat diskresi seperti terurai sebagai berikut; Hukum Administrasi Inggris; discretionary power, Hukum Administrasi Jerman; Ermessen (bukan "Freies Ermessen"), discretionarie bevoegheden, Hukum Administrasi Belanda; Vrij bevoegdheid. Berdasarkan esensi dari istilah dan konsep-konsep tersebut, dalam Rancangan Undang-undang tentang Administrasi Pemerintah digunakan istilah diskresi. ${ }^{7}$

Sebagai tambahan bahwa Hakikat istilah diskresi digunakan sebagai lawan dari wewenang terikat gebonden bevoegdheid. Esensi: ada pada pilihan untuk melakukan tindakan pemerintahan. Pilihan berkaitan dengan; a) rumusan norma, misalnya -tersangka dapat ditahan....-dalam keadaan tertentu-....-seharusnya-....-sepatutnya-...,dan demi kepentingan umum dan lain-lain; b) kondisi faktual, misalnya -bencana dan keadaan darurat dan lain sebagainya. ${ }^{8}$

Terkait dengan perizinan, semangat peraturan per-undang-undangan yang memberikan "support" kepada negara sebagai penyelenggara negara telah mencerminkan suatu pelaksanaan roda pemerintahan, hanya terdapat pertanyaan, apakah roda pemerintahan tersebut telah sesuai dengan teori-teori tentang penyelenggaraan negara.

Pada tataran norma, penyelenggaraan negara dalam konteks penegakkan hukum tidak dapat dipungkiri bahwa penegakkan tersebut harus mengacu pada moral hukum itu sendiri serta merupakan pula bagian dari suatu intrinsik hukum 9 . Sebab, moral hukum inilah yang menjadi tonggak atau dasar pada penegak hukum (law enforcer). Kalo penegakkan hukum itu tanpa moral, maka akan pasti tercipta suatu kegagalan penegakkan itu sendiri. Dalam Fuller

\footnotetext{
$5 \quad$ Bega Ragawino, Hukum Administrasi Negara, Universitas Padjadjaran Bandung, 2006.h.42. Dalam penjelesannya Unsur-unsur Ermessen; (a). Dilakukan untuk kepentingan umum/ kesejahteraan umum. (b) Dilakukan atas inisiatif administrasi Negara itu sendiri. (c) Untuk menyelesaikan masalah konkrit dengan cepat yang timbul secara tibatiba.(d). Tindakan itu dimungkinkan oleh hukum.

6 Ibid, h. 42.

Philipus.M Hadjon, Tatiek Sri Djatmiati, G.H.,Addink, J.B.J.M,Ten Berge, Op.Cit, h.14-15

Ibid, h.15.

9 Peter Mahmud Marzuki, Pengantar Ilmu Hukum, Jakarta: Penerbit Prenada Media Group, 2009, h.50.
} 
menegaskan bahwa:

the morality of law, eight ways to fail to make law; 1) Failure to make rules public to those required to observe them; 2) Failure to establish rules at all, leading to absolute uncertainty; 3) Improper use of retroactive lawmaking; 4) Failure to make comprehensible rules; 5) Making rules which contradict each other; 6) Making rules which impose requirements with which compliance is impossible; 7) Changing rules so frequently that the required conduct becomes wholly unclear; 8) Discontinuity between the stated content of rules and their administration in practice. ${ }^{10}$

Meskipun demikian secara teori terdapat teori hukum sebagai dasar ratio legis dari suatu penyeleggaraan negara dalam rangka membangun dan merokonstruksi suatu pelaksanaan pemerintahan, sehingga dengan adanya teori hukum tersebut dapat memetakan batasan-batasan serta menempatkan pada kesesuaian norma hukum yang telah ada. Menurut Bruggink dalam Sukardi memaparkan bahwa terdapat dua cabang teori hukum teori hukum sebagai teori tentang hukum positif dan teori hukum tentang dokmatik hukum.

Teori hukum sebagai teori tentang hukum positif mempelajari aspek-aspek diluar yang menjadi obyek dogmatik hukum. Tujuannya semata-mata teoritik yaitu mengolah masalahmasalah umum berkenaan dengan hukum positif. Obyeknya tidak hanya hukum nasional tertentu. Contoh obyek teori hukum: pengertian hukum, definisi hukum, sifat norma hukum, sistem hukum dan keberlakuan hukum. Teori hukum tentang dokmatik hukum dan teori-teori tentang kegiatan-kegiatan yang terkait pada pembentukan hukum dan penemuan hukum. ${ }^{11}$

Lain pula pokok-pokok pemikiran yang dikembangkan Hans Kelsen dalam Jimly Asshiddiqie yakni terdapat tiga masalah utama, tentang toeri hukum, negara, dan hukum internasional. Namun yang menjadi sorotan dalam makalah tersebut adalah teori umum yang mana meliputi dua aspek, yaitu aspek statis (nomostatics) yang melihat perbuatan yang diatur oleh hukum, dan aspek dinamis (nomodinamic) yang melihat hukum yang mengatur perbuatan tertentu. Friedmann mengungkapkan dasar-dasar esenesial dari pemikiran Kelsen sebagai berikut; (a) Tujuan teori hukum, setiap ilmu pengetahuan, adalah untuk mengurangi kekacauan dan kemajemukan menjadi kesatuan, (b) Teori hukum adalah ilmu pengetahuan mengenai hukum yang berlaku, bukan mengenai hukum yang seharusnya. (c) Hukum adalah ilmu pengetahuan normatif, bukan ilmu alam. (d) Teori hukum sebagai teori tentang norma-norma, tidak ada hubungannya dengan daya kerja norma-norma hukum. (e) Teori hukum adalah formal, suatu teori tentang cara menata, mengubah isi dengan cara yang khusus.

Hubungan antara teori hukum dan sistem yang khas dari hukum positif ialah hubungan apa yang mungkin dengan hukum yang nyata. Lebih lanjut, apa yang disebut dengan The Pure Theory of Law, mendapatkan tempat tersendiri karena berbeda dengan dua kutub pendekatan yang berbeda antara mazhab hukum alam dengan positivism empiris. Beberapa ahli menyebut

\footnotetext{
1964.

10 Lon L. Fuller, The Morality Of Law, (Eight Ways To Fail To Make Law), USA: Yale University Press,

11 J.J.H. Bruggink, Refleksi tentang Hukum, Alih Bahasa Arief Sidharta, Bandung: PT Citra Aditya Bakti, 1999.
} 
pemikiran Kelsen sebagai jalan tengah dari dua aliran hukum yang telah ada sebelumnya. ${ }^{12}$ Dalam bukunya jilid I, pengantar ilmu hukum tata negara, Jimly Asshiddiqie mejelaskan bahwa terdapat tujuan dan hakikat konstitusi. Menurutnya, dikalangan para ahli hukum, pada umumnya dipahami bahwa hukum mempunyai tiga tujuan pokok, yaitu (i) keadilan (justice), (ii) kepastian (certainty atau zekerheid), dan (iii) kebergunaan (utility). Keadilan itu sepadan dengan keseimbangan (balance, mizan) dan kepatuhan (equity), serta kewajaran (proportionality). Sedangkan, kepastian hukum terkait dengan ketertiban (order) dan ketentraman. Sementara, kebergunaan diharapkan dapat menjamin bahwa semua nilai-nilai tersebut akan mewujdukan kedamaian hidup bersama. Oleh karena itu konstitusi itu sendiri adalah hukum yang dianggap paling tinggi tingkatannya, maka tujuan konstitusi sebagai hukum tertinggi itu juga untuk mencapai dan tujuan tertiggi. Tujuan yang dianggap tertinggi itu adalah; (i) keadilan, (ii) ketertiban, dan (iii) perwujudan nilai-nilai ideal seperti kemeridekaan atau kebebasan dan kesejahteraan atau kemakmuran bersama, sebagaimana dirumuskan sebagai tujuan bernegara oleh paran pendiri negara (the founding fathers and mothers). ${ }^{13}$

\section{Konsep Algemene Beginselen van Behoorlijk Bestuur atau Asas Umum Pemerintahan Yang Baik sebagai Penopang Diskresi Pemerintah.}

Konteks General Principle of Good Governance, G.H Addink menjelaskan bahwa dalam hukum administrasi memang diperdebatkan apakah penggunaan kata (term) governance sama dengan administration. ${ }^{14}$ Dari sudut pandang administrasi, konsep Good Governance berkaitan dengan aktivitas pelaksanaan fungsi untuk menyelenggarakan kepentingan umum.

Tata kepemerintahan yang baik atau Good Governance berkenaan dengan penyelenggaraan tiga tugas dasar pemerintah yaitu; 1) Menjamin keamanan setiap orang dan masyarakat (to guarantee the security off all person and society itself); 2) Mengelola suatu struktur yang efektif untuk sektor publik, sector swasta, dan masyarakat (to manage an effective frame work for the public sector, the private sector, and civil society); 3) Memajukan sasaran ekonomi, social dan bidang lainnya dengan kehendak rakyat (to promote economic, social and other aims in accordance with the wishes of the population).

Tata kepemerintahan yang baik atau good governance berhubungan sangat erat dengan hak-hak asasi. Dalam hukum administrasi, negara-negara anggota Uni Eropa telah menyelenggarakan berbagai kegiatan ilmiah membahas prinsip-prinsip Good Governance dikaitkan dengan hukum administrasi Eropa. Telaah hukum administrasi berkenaan dengan fungsi dan pendekatan dalam hukum administrasi, jelaslah menunjukkan bahwa penggunaan kekuasaan memerintah dan berkenaan dengan perilaku aparat dalam melaksanakan pelayanan kepada masyarakat. Penggunaan kekuasaan memerintah bertumpu atas asas legalitas

\footnotetext{
12 Jimly Asshiddiqie, M.Ali Safa'at, Teori Hans Kelsen Tentang Hukum, Jakarta: Penerbit Sekretariat Jenderal dan Kepaniteraan Mahkamah Konstitusi Republik Indonesia, 2006, h.8-9.

13 Jimly Asshiddiqie, Pengantar Ilmu Hukum Tata Negara, Jakarta: Penerbit Sekretariat Jenderal dan Kepaniteraan Mahkamah Konstitusi Republik Indonesia, h.149-150.

14 G.H, Addink, Reader, Principles of Good Governance, Faculty of Law, Economic, and Governance, University of Utrecht. 2010, p.13.
} 
(rechtmatigheid). Pengujian segi legalitas atau segi rechtmatigheid terutama merupakan fungsi judicial control (bandingkan dengan ketentuan Pasal 53 ayat (2) Undang-undang Nomor 5 Tahun 1986 jis Undang-undang Nomor 9 Tahun 2004 dan Undang-undang Nomor 51 Tahun 2009). ${ }^{15}$

Karakteristik tata kepemerintahan yang baik atau Good Governance apabila dapat diterapkan dalam penegakkan hukum tentang korupsi melalaui system peradilan korupsi, maka tujuan reformasi hukum dan keadilan di Indoensia niscaya akan terwujud secara simultan. Namun demikian, semua itu sangat tergantung pada sumber daya manusia yang menjadi penegak hukum. Terkait dengan persoalan demikian, terdapat pandangan bahwa dalam melaksanakan tugas dan keweangannya, aparatur Negara (penegak hukum) harus mengindahkan dan dibatasi asas-asas sebagai berikut; 1) Asas Rehctmatigheid; 2) Asas Legalitas (wetmatigheid); 3) Asas diskresi (Ermessen), baik yang bersifat bebas maupun yang terikat; 4) Asas-asas umum pemerintahan yang baik (the general principle of good administration) $)^{16}$

Terdapat pula sumber penjelasan lain bahwa asas umum pemerintahan yang baik mulai dikenal di Indonesia sejak awal 1953 melalui tulisan G.A van Poelje, walaupun pada waktu itu belum mendapat perhatian dari kalangan pemikir hukum administrasi Negara. Kuntjoro Purbopranoto menambahkan dua asas; asas kebijaksanaan (sapienta); dan asas penyelenggaraan kepentingan umum (principle of public service). Khusus untuk penyelenggaraan tata pemerintahan di Indonesia asas-asas tersebut harus disesuaikan dengan pokok-pokok Pancasila dan Undang-undang Dasar 1945. Walaupun asas-asas tersebut bukan berasal dari peradilan administrasi (baru berlaku pada tahun 1976), tetapi mulai memperoleh perhatian dari kalangan hukum administrasi Negara. ${ }^{17}$

Seiring perkembangan asas-asas umum pemerintahan yang baik, G.H Addink menambahkan asas-asas yang menyentuh pada hak asasi manusia. Harus disadari bahwa kedua makna tersebut asas-asas umum pemerintahan yang baik dan hak asasi manusia saling berkaitan erat dan saling berinteraksi dengan prinsip lain sepertihalnya transparansi dan partisipasi dan lain sebagainya. Sebagaimana penjelasan Addink;

Both groups of norms for the government (human rights norms and good governance norms) can only be realized by each other: human rights needs good governance and good governance needs human rights. So it means that there is an interaction between these two types of norms and even several of these norms are the same. For example, the transparency and the participation principles, which are principles of good governance, can be found in several international human rights treaties. ${ }^{18}$

Dengan demikian bahwa salah satu yang melandaskan adanya suatu penopang atau pondasi

15 Philipus.M Hadjon, Paulus Effendie Lotulung, H.M. Laica.Marzuki, Tatiek.Sri Djatmiati, I Gusti

Ngurah Wairocana, Hukum Administrasi dan Good Governance, Jakarta: Universitas Trisakti, 2010, h.10.

16 Sidik Sunaryo, Sistem Peradilan Pidana, Malang: UMM Press, 2004, h 455.

17 Safri Nugraha, Anna Erliyana, Sri Mamudji, Tri Hayati, Harsanto Nursadi, Eka Sri Sunarti, Dian Puji

N, Simatupang, Hukum Administrasi Negara, Center For Law And GG (GG)Studies CLGS), Depok: Fakultas Hukum Universitas Indonesia, 2007, h.67-68.

18 G.H. Addink, Human Rights \& Good Governance, SIM special 34, Edited by Henk Addink, Gordon Anthony, Antoine Buyse \& Cees Flinterman, Utrecht, 2010. 
suatu hakikat diskresi dalam hal ini yakni izin oleh pemerintah khusunya dibidang pertambangan adalah adanya tata kelola pemeritahan yang baik atau Good Governancne sehingga tercipta suatu harmonisasi sebagai penyelenggara negara.

\section{Pelanggaran Tindak Pidana Dalam Pemberian Izin Pertambangan}

Maladministrasi dalam pemberian izin pertambangan oleh pejabat berwenang sangat berpotensi terhadap tindak pidana. Perbuatan ini sangat berpotensi mengarah pada penyalahgunaan wewenang. Maladministrasi ini dapat dianalisa melalui karakter wewenang dan keabsahan bertindak pemerintah. Meskipun demikian, tindak semua penyalahgunaan wewenang itu dapat dipidana, kecuali terdapat adanya suatu kerugian keuangan negara. Seorang pejabat pemerintah yang tidak memiliki wewenang untuk melakukan suatu tindakan hukum tertentu, tidak dapat dinyatakan sebagai pelaku penyalahgunaan wewenang, apabila telah melakukan tindakan atau keputusan tata usaha negara yang bukan lingkup wewenangnya. Tidak ada wewenang, maka tidak ada penyalahgunaan wewenang. ${ }^{19}$

Dalam pengelolaan dan pengawasan pertambangan, penggunaan wewenang mempunyai kaitan erat dengan kebijakan. Pemberian izin pertambangan merupakan keputusan pejabat berwenang. Sifat keputusan ini dapat dikaji melalui karakter wewenang distribusi. Fungsi dan wewenang pemerintah daerah sebagaimana telah ditentukan dalam Pasal 18, 18A, 18B UUD 1945, Pasal 6, 7, dan 8 UU No.4 2009 serta Pasal 10 (2), 13 (b), dan Pasal 25 (g) UU No. 32 Tahun 2004.

Disisi lain, pernyataan Laica Marzuki ${ }^{20}$ dalam mengomentari tentang kebijakan beleidregel yang tidak dapat diajukan ke depan hakim atau tidak dapat dihukum, karena kebijakan itu bukan merupakan bagian dari peraturan perundang-undangan. Pada hakekatnya kebijakan beleidsregel itu adalah bagian dari kebebasan bertindak pemerintah discretionary power atau lazim dikenal dengan freies ermessen. Namun, bilamana terbukti seorang pejabat menyalahgunakan kebijakannya abuse of power, maka akan terdapat dua macam pertanggungjawaban; tanggung jawab jabatan dan tanggung jawab pribadi. Akan tetapi hal ini, tergantung pada klasifikasi tindakan yang dilakukan.

Dalam uraian Laica Marzuki ${ }^{21}$ mengutarakan 3 (tiga) komponen utama dari peraturan kebijakan yakni: komponen subyektum yang berarti bahwa peraturan kebijakan (beleidsregel) dibuat oleh badan atau pejabat tata usaha negara sebagai perwujudan penggunaan freies ermessen (discretionery power) dalam bentuk tertulis yang diumumkan keluar lalu mengikat warga. Selanjutnya adalah komponen materi (substantif) muatan (isi) kebijakan (beleidregels) memuat aturan umum (algemene regel) tersendiri yang melampaui cakupan kaidah (materialsphere) perundang-undangan yang dibuatkan pengaturan operasional.Komponen berikutnya adalah komponen kewenangan. Badan atau pejabat tata usaha negara yang membuat peraturan

\footnotetext{
19 Adang Oktori, Loc.Cit, h. 66.

20 Laica Marzuki, Loc.Cit, h. 56.

21 Ibid.
} 
kebijakan (beleidsregels) tidak memiliki kewenangan perundang-undangan (geen bevoegheid tot wetgeving) namun secara langsung mengikat para warga, sebagaimana halnya dengan kaidah-kaidah juridishe regels.

Parameter suaut penyalahgunaan wewenang, dapat dilihat melalui asas spesialitas (specialiteitbeginsel). Dalam pandangan Nur Basuki Minarno ${ }^{22}$ tentang konsep hukum administrasi, mengatakan setiap pemberian wewenang kepada suatu badan atau kepada pejabat administrasi negara selalu disertai dengan "tujuan dan maksud" diberikannya wewenang itu, sehingga penerapan wewenang itu harus sesuai dengan tujuan dan maksud diberikannya wewenang itu. Dalam hal penggunaan wewenang tersebut tidak sesuai dengan tujuan dan maksud pemberian wewenang itu maka telah melakukan penyalahgunaan wewenang (detournement de pouvoir). Parameter tujuan dan maksud pemberian wewenang dalam menentukan terjadinya penyalahgunaan wewenang dikenal dengan asas spesialitas (specialialiteitsbeginsel). Asas ini dikembangkan oleh Mariette Kobussen dalam bukunya yang berjudul De Vrijheid Van De Overheid. Lebih lanjut dikatakan, secara substansial specialialiteitsbeginsel mengandung makna bahwa setiap kewenangan memiliki tujuan tertentu. Dalam kepustakaan hukum administrasi sudah lama dikenal asas zuiverheid van oogmerk (ketajaman arah atau tujuan). Menyimpang dari asas ini akan melahirkan detournement de pouvoir.

Menurut Indriyanto Seno Adji ${ }^{23}$ menguraikan pengertian penyalahgunaan wewenang sebagaimana mengutip pendapatnya Jean Rivero dan Waline dalam kaitannya detournement de pouvoir dengan freis ermessen, penyalahgunaan wewenang dalam hukum administrasi dapat diartikan dalam 3 (tiga) wujud yaitu: 1) Penyalahgunaan kewenangan untuk melakukan tindakantindakan yang bertentangan dengan kepentingan umum untuk menguntungkan kepentingan pribadi, kelompok atau golongan; 2) Penyalahgunaan kewenangan dalam arti bahwa tindakan pejabat tersebut adalah benar diajukan untuk kepentingan umum, tetapi menyimpang dari tujuan apa kewenangan tersebut diberikan oleh undang-undang atau peraturan-peraturan lainnya; 3) Penyalahgunaan kewenangan dalam arti menyalahgunakan prosedur yang seharusnya dipergunakan untuk mencapai tujuan tertentu, tetapi telah menggunakan prosedur lain agar terlaksana.

Dalam paparan seminar nasional, Philipus M.Hadjon ${ }^{24}$ menyatakan bahwa asas legalitas adalah merupakan unsur universal konsep negara hukum apapun tipe negara hukum yang dianut suatu negara. Begitu juga dalam hukum pidana yang menekankan pada asas legalitas dalam wujudnya sebagai konsep "nullum delictum sine lege”. Dikalangan para ahli, konsep ini masih diperdebatkan mengenai asas berlakunya hukum tersebut. Namun dalam konteks hukum administrasi, asas legalitas dalam wujudnya sebagai "wetmatigheid van bestuur" dapat

\footnotetext{
22 Nur Basuki Minarno, Penyalahgunaan Wewenang Dalam Pengelolaan Keuangan Daerah Yang Berimplikasi Tindak Pidana Korupsi, Loc.Cit, h. 80.

23 Indriyanto Seno Adji, Korupsi Kebijakan Aparatur Negara Dan Hukum Pidana, Loc.Cit, h. 54.

24 Philipus M.Hadjon, "Discretionary Power dan Asas-Asas Umum Pemerintahan Yang Baik (AAUPB)", Makalah Disampaikan Dalam Seminar Nasional Aspek Pertanggung jawaban Pidana Dalam Kebijakan Publik Dari Tindak Pidana Konsep Semarang 6-7 Mei 2004, Semarang, 2004, h. 1.
} 
dikatakan tidak memadai. Dengan tidak memadainya asas ini, pada dasarnya berakar pada hakikat kekuasaan pemerintah. Kekuasaan pemerintahan di Indonesia sangat populer disebut dengan eksekutif dalam prakteknya tidaklah murni sebuah kekuasaan eksekutif (melaksanakan undang-undang). Oleh karena itu, dalam kaitan dengan hal ini, Philipus M. Hadjon ${ }^{25}$ menguraikan pendapat N.E. Algra, et al : "pada kepustakaan Belanda jarang menggunakan istilah "uitvoerende macht",melainkan menggunakan istilah yang populer "bestuur" yang dikaitkan dengan "sturen" dan "sturing". Makna "Bestuur" dirumuskan sebagai lingkungan kekuasaan negara di luar lingkungan kekuasaan legislatif dan kekuasaan yudisial”.

\section{Bagan $^{26}$ : \\ Hubungan Asas Legalitas, Asas Spesialitas, dan AAUPB}

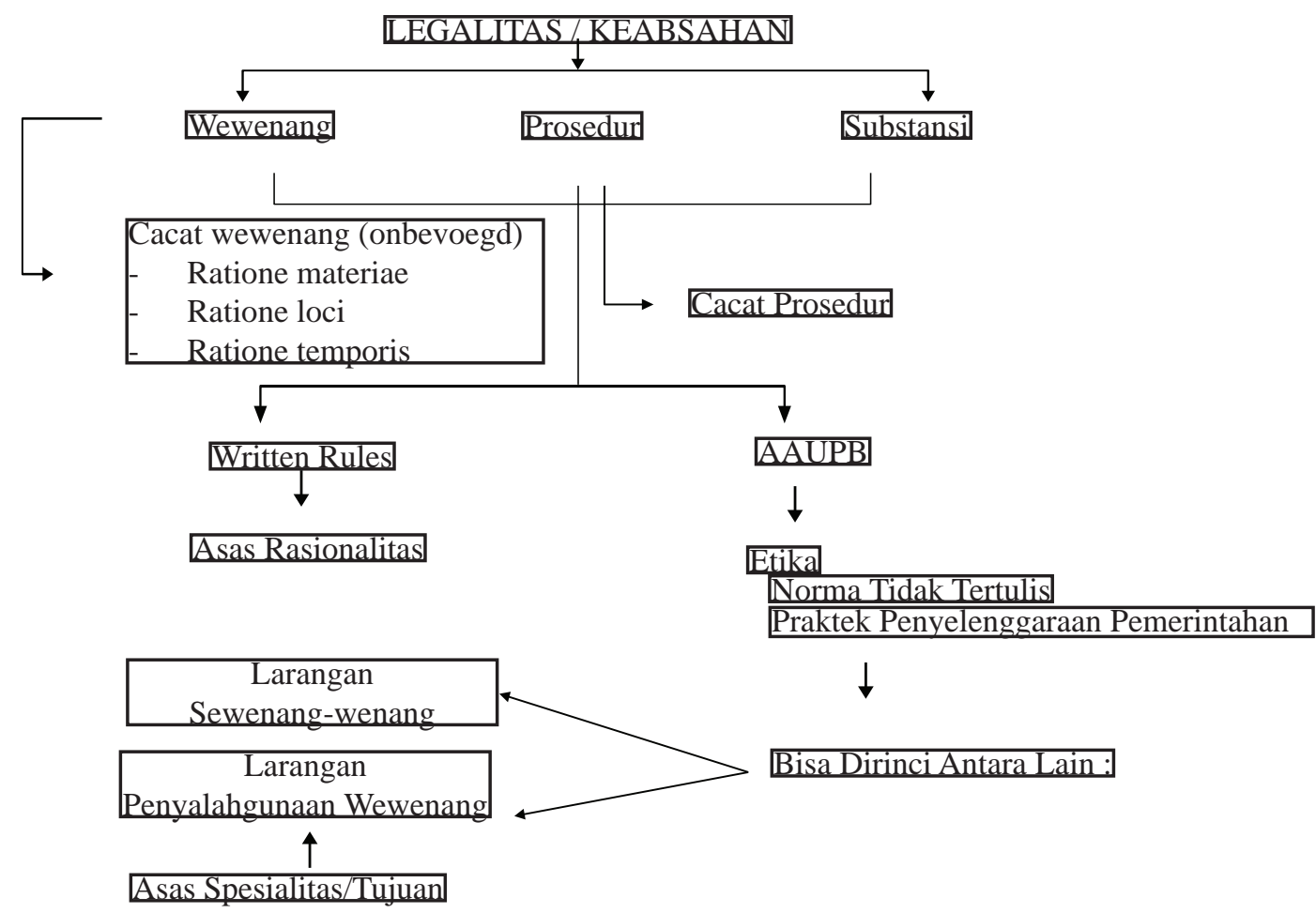

Gambar 1. hubungan asas legalitas, asas spesialitas, dan AAUPB

Lanjut pada pendapat Philipus M.Hadjon ${ }^{27}$ menjelaskan tentang konsep “bestuur” yang membawa implikasi kekuasaan pemerintahan tidaklah semata sebagai kekuasaan terikat, tetapi juga merupakan suatu kekuasaan bebas (vrij bestuur, Freies Ermessen, discretionary power). Menurut Ten Berge dalam Philipus M. Hadjon ${ }^{28}$ mengutarakan kekuasaan bebas itu meliputi kebebasan kebijakan dan kebebasan penilaian. Kebebasan kebijakan (wewenang diskresi dalam arti sempit) artinya bila peraturan perundang-undangan memberikan wewenang tertentu kepada organ pemerintah, sedangkan organ tersebut bebas untuk (tidak) menggunakannya meskipun

\footnotetext{
25 Ibid.

Nur Basuki Minarno, Loc.Cit, h.94.

27 Ibid.

28 Ibid, h.2-3.
} 
syarat-syarat bagi penggunaannya secara sah dipenuhi. Sedangkan kebebasan penilaian (wewenang diskresi dalam arti yang tidak sesungguhnya) adalah hak yang diberikan organ pemerintah untuk menilai secara mandiri dan eklusif apakah syarat-syarat bagi pelaksanaan suatu wewenang secara sah telah terpenuhi.

Meskipun demikian, Philipus M. Hadjon ${ }^{29}$ menyatakan untuk memudahkan memberikan pemahaman tentang kekuasaan bebas atau kekuasaan diskresi dengan cara melihat ruang lingkupnya. Kekuasaan bebas atau kekuasaan diskresi meliputi; kewenangan untuk memutus sendiri, dan kewenangan interpretasi terhadap norma-norma tersamar (vage normen).

Dalam pernyataan lainnya, norma dan sanksi di dalam hukum pidana dapat dikaji melalui bekerjanya tujuan hukum pidana dan pemidanaan, dapat dikatakan bahwa hukum pidana di dalam perumusannya pada tiap-tiap peraturan perundang-undangan harus memuat dua bagian pokok yaitu norma dan sanksi.

Menurut D. Hazewinkel-Suringa dalam Loebby Loqman ${ }^{30}$, pemikiran yang terkandung didalam rumusan tersebut ditemukan juga dalam ajaran Montesquieu mengenai ajaran pemisahan kekuasaan, bukan hakim yang menyebutkan apa yang dapat dipidana, pembuat undang-undang menciptakan hukum. Pembuat undang-undang tidak saja menetapkan norma tetapi juga harus diumumkan sebagai norma-norma sebelum perbuatan. Manifestasi pertama kali di dalam Konstitusi Amerika pada tahun 1783 dan berikutnya dan kemudian di dalam Pasal 8 Declaration desdroits de l'homme et du citoyen tahun 1789. Akhirnya muncul di dalam Pasal 4 Code Penal dan WvS Belanda yang kemudian turun ke KUHP Indonesia, dan KUHP Belgia pada Pasal 2. Sebagaimana telah dikemukakan diatas, Asas Legalitas dalam KUHP Indonesia (yang berasal dari WvS. Ned.) ini sebenarnya merupakan peraturan yang tercantum dalam Declaration Des Droits DeL'Homme Et Du Citoyentahun 1789, yang berbunyi: "Tidak ada orang yang dapat dipidana selain atas kekuatan undang-undang yang sudah ada sebelumnya".

Menurut Djojodigoeno dalam Andi Hamzah ${ }^{31}$ istilah norma lazim dipakai meskipun terdapat penulisan lain yang mengganti istilah tersebut dengan kaidah. Norma tersebut mempunyai nilai-nilai dalam suatu rangkaian konsepsi abstrak yang hidup di antara kelompok manusia sebagai ketentuan yang harus ditaati oleh setiap orang dalam pergaulan hidup bermasyarakat, dan mempunyai tugas menjamin ketertiban hukum dalam masyarakat. Pembentuk hukum terutama dari pembentuk undang-undang (wetgiver) dapat menetapkan norma, sehingga sebagian besar norma-norma tersebut dapat dijumpai dalam undang-undang. Bentuk norma dalam undang-undang atau peraturan lainnya pada dasarnya perbuatan yang dilarang atau keharusan berbuat (verboden of geboden). Sanksi mengandung inti berupa suatu ancaman pidana (strafbedreiging), dan mempunyai tugas agar norma yang sudah ditetapkan

29 Ibid, h. 6.

30 Loebby Loqman, "Perkembangan Asas Legalitas Dalam Hukum Pidana Indonesia”, Makalah Disampaikan Pada Seminar Tentang Asas-Asas Hukum Pidana Nasional Diselenggarakan Oleh: Badan Pembinaan Hukum Nasional Departemen Kehakiman Dan Hak Asasi Manusia R.I , Bekerjasama Dengan Fakultas Hukum Universitas Diponegoro Semarang, Puri Suite Hotel Ciputra, Semarang, 26 - 27 April 2004. Dalam penjelasan D. Hazewinkel-Suringa, Inleiding tot de studie van het Nederlandse Strafrecht, 1983, h. 380.

31 Andi Hamzah, Asas-asas Hukum Pidana, Jakarta: P.T Rinaka Cipta, 1994. h. 9. 
dapat ditaati dan sebagai akibat hukum atas pelanggaran norma. Selain pandangan tersebut, Vos dalam Andi Hamzah ${ }^{32}$ menyebutkan adanya pendapat yang menyimpang dari pandangan yang lazim, seperti yang dikemukakan oleh Karl Binding bahwa norma tidak terdapat di dalam undang-undang tapi di dalam kesadaran hukum yang tidak tertulis (ongeschreven publieke recht liggen).

Hukum pidana, menurut Jan Ramellink, seharusnya ditujukan untuk menegakkan tertib hukum, melindungi masyarakat hukum. Manusia satu persatu di dalam masyarakat saling bergantung; kepentingan mereka dan relasi antar mereka ditentukan dan dilindungi oleh normanorma. Penjagaan tertib sosial ini untuk bagian terbesar sangat tergantung pada paksaan. Jika norma-norma tidak ditaati, akan muncul sanksi, kadangkala yang berbentuk informal, misalnya perlakuan acuh tak acuh dan kehilangan status penghargaan sosial. Namun bila menyangkut soal yang lebih penting, sanksi (hukum), melalui tertib hukum negara yang melengkapi penataan sosial, dihaluskan, diperkuat dan dikenakan kepada para pelanggar norma tersebut. ${ }^{33}$

Konsep dan argumen ahli diatas, bila dikaitkan dengan perbuatan maladministrasi, maka akan ditemukan perbuatan melanggar norma sosial dan norma hukum, bahkan sebagian kalangan berkomenter bahwa maladministrasi merupakan "pintu masuk" tindak pidana. Oleh karena itu, dengan adanya norma dan sanksi hukum dalam konteks hukum pidana dapat dikatakan sebagai salah bentuk embrio unsur-unsur tindak pidana, seperti halnya pemalsuan dalam mengeluarkan izin pertambangan dan masih banyak lagi terdapat kasus-kasus lainnya.

Namun, ada hal yang menarik dari paparan ini yakni jika ditelaah lebih mendalam kreteria maladministrasi dalam Hendra Nurtjahjo et $\mathrm{al}^{34}$, maka akan ditemukan kriteria yang sama dengan unsur-unsur dalam tindak pidana. Namun kreteria ini harus dibuktikan terlebih dahulu. Contoh kreteria maladministrasi yang sama dalam unsur-unsur tindak pidana ini adalah (1) perilaku dan perbuatan melawan hukum, (2) perilaku dan perbuatan melampaui wewenang, (3) penyalahgunaan dengan menggunakan wewenangnya untuk tujuan lain dari yang menjadi tujuan wewenang tersebut. Hal tersebut teradpat kesimbangunan dengan pernyataan Jean Rivero dan Waline dalam Indriyanto Seno Adji ${ }^{35}$ yang menguraikan pengertian penyalahgunaan kewenangan dalam Hukum Administrasi dapat diartikan dalam 3 wujud, yaitu;

32 Ibid, h. 11.

33 Jan Remmelink, Hukum Pidana (Komentar atas Pasal-Pasal Terpenting dari Kitab Undang-Undang Hukum Pidana Belanda dan Padanannya dalam Kitab Undang-Undang Hukum Pidana Indonesia), Jakarta: PT Gramedia Pustaka, 2003, h. 14.

${ }^{34}$ Hendra Nurtjahjo, et al, Loc.cit, h. iii. Lebih lanjut disebutkan terdapat Dalam hukum positif Indonesia ada 9 kriteria yang menjadi kategori maladministrasi (1) Perilaku dan perbuatan melawan hukum (2) Perilaku dan perbuatan melampaui wewenang, (3) Menggunakan wewenang untuk tujuan lain dari yang menjadi tujuan wewenang tersebut, (4) Kelalaian (5) Pengabaian kewAdjiban hukum (6) Dalam penyelenggaraan pelayanan publik (7) Dilakukan oleh Penyelenggara Negara dan pemerintahan (8) Menimbulkan kerugian materiil dan/ atau immaterial (9) Bagi masyarakat dan orang perseorangan.Sembilan kategori itu akan dijelaskan dalam buku praktis ini agar masyarakat mudah untuk memahami apa itu maladministrasi. Upaya untuk menjelaskan secara gamblang tentang maladministrasi ini juga merupakan cara agar masyarakat dan penyelenggara pelayanan publik tidak melakukan tindakan yang masuk dalam kategori maladministrasi. Dengan kata lain hal ini merupakan upaya pencegahan maladministrasi. Meskipun sudah diterangkan di dalam undangundang, ternyata masih banyak masyarakat Indonesia yang belum memahami definisi atau pengertian maladministrasi, bahkan para akademisipun masih mempertanyakan hal ini.

35 Indriyanto Seno Adji, ,Loc.Cit, h.54. 
1) Penyalahgunaan kewenangan untuk melakukan tindakan-tindakan yang bertentangan dengan kepentingan umum atau untuk menguntungkan kepentingan pribadi, kelompok atau golongan; 2) Penyalahgunaan kewenangan dalam arti bahwa tindakan pejabat tersebut adalah benar ditujukan untuk kepentingan umum, tetapi menyimpang dari tujuan apa kewenangan tersebut diberikan oleh Undang-undang atau peraturan-peraturan lain; 3) Penyalahgunaan kewenangan dalam arti menyalahgunakan prosedur yang seharusnya dipergunakan untuk mencapai tujuan tertentu, tetapi telah menggunakan prosedur lain agar terlaksana.

Kriteria maladministrasi juga terdapat dalam Pasal 2 dan 3 UU No. 31 Tahun 1999 jo. UU No.20 Tahun 2001 Pemberantasan Tindak Pidana Korupsi. Berkaitan dengan maladministrasi di bidang pertambangan, dalam penelitian ini ditemukan kreteria baru maladministrasi yakni contoh kasusnya dapat dilihat pada perkara No. 227/PID.B/2012/PN.SMD, adanya pemalsuan surat izin pertambangan yang sengaja dilakukan oleh pejabat berwenang, sehingga perbuatan tersebut termasuk kategori tindak pidana sebagiaman ditentukan dalam Pasal 263 dan Pasal 55 (1) KUHP. Pasal 22 (4) UU No. 8 Tahun 1981 tentang KUHAP.

Paparan dibawah ini adalah analisan hukum bentuk-bentuk maladministrasi dalam pemberian izin yang berimplikasi tindak pidana. Pada kasus No.07/PID/B/TPK-2011.PN PDG maladministrasi dimaknai inkompeten (bukan tugas) dalam hukum administrasi dan tidak menyerahkan uang jaminan kesungguhan dan land-rent perusahaan tambang ke kas daerah dan kas negara. Pada kasus No. 227/PID.B/2012/PN.SMD perbuatan maladministrasi adalah sengaja memalsukan surat baik itu sebagian atau seluruhnya dan menghilangkan dokumen sebagian atau seluruhya. Kemudian pada kasus Nomor : 01 /Tipikor / 2013 / PT. Sultra maladministrasi yaitu tidak menyetorkannya ke kas negara melalui bendahara penerima sebagai Penerimaan Negara Bukan Pajak (PNBP) sebagaimana ketentuan Pasal 3 Peraturan Pemerintah RI Nomor 46 Tahun 2002 dan penggunaannya tidak dibuat pertanggung jawaban oleh Terdakwa. Analisa pemaparan beberapa kasus diatas, dapat disimpulkan bahwa pejabat berwenang yang melakukan perbuatan maldministrasi yang berimplikasi tindak pidana berupa: menyalahgunakan wewenang, tidak menyerahkan uang jaminan kesungguhan dan landrent perusahaan tambang ke kas daerah dan kas negara yakni Penerimaan Negara Bukan Pajak (PNBP) sebagaimana ketentuan Pasal 3 PP RI Nomor 46 Tahun $2002^{36}$ dan penggunaannya tidak dibuat pertanggung jawaban oleh Terdakwa. Oleh karena itu, negara mengalami kerugian. Selain daripada itu, memalsukan surat baik itu sebagian atau seluruhnya dan menghilangkan dokumen sebagian atau seluruhya.

\section{Kesimpulan}

Ketidakjelasan pasal 1 angka 3 UU No.37 Tahun 2008 dalam merumuskan maladministrasi, hal ini ditandai dengan rincian species bentuk-bentuk maladministrasi seperti melawan hukum, melampaui wewenang, dan belum menjabarkan dengan jelas makna

${ }^{36}$ Dalam Pasal 3 ditentukan Jenis Penerimaan Negara Bukan Pajak dari kegiatan Pelayanan Pendaftaran Tanah sebagaimana dimaksud dalam Pasal 2 huruf a terdiri dari : a. Pelayanan Pengukuran dan Pemetaan Bidang Tanah; b. Pelayanan Pendaftaran Tanah untuk Pertama Kali; c. Pelayanan Pemeliharaan Data Pendaftaran Tanah. 
penyalahgunaan wewenang. Maladministrasi yang tersebar dalam undang-undang sektoral, namun belum ada undang-undang umum yang mengatur terhadap hal tersebut. UU No. 37 Tahun 2008 memang memberikan batasan tentang maladministrasi, namun batasannya sangat sempit dan memerlukan penafsiran yang cukup signifikan.

Di samping itu, rumusan maladministrasi masih mencampuradukan antara kesalahan dan atau tanggung jawab jabatan dengan kesalahan dan atau tanggung jawa pribadi. definisi maladministrasi. Terkait dengan ketentuan pidana UU No.4 Tahun 2009, formulasi pasal 165 tidak menentukan unsur kesalahan serta kesengajaan dan kelapaan dolus dan culpa berkaitan dengan pertanggungjawaban pidana. Di samping itu, ketentuan pidana dalam UU No. 4 Tahun 2009 belum memprekripsikan tentang kejahatan jabatan secara utuh, hanya memuat satu pasal yakni pasal 165. Padahal dalam berbagai kasus kepala daerah terkait dengan izin pertambangan di beberapa daerah, begitu banyaknya tumpang tindih izin yang disebabkan oleh maladministrasi pejabat berwenang.

\section{Daftar Bacaan}

\section{Buku}

Addink, G.H, Reader, Principles of Good Governance, Faculty of Law, Economic, and Governance, University of Utrecht. 2010

--------, Human Rights \& Good Governance, SIM special 34, Edited by Henk Addink, Gordon Anthony, Utrecht, Antoine Buyse \& Cees Flinterman, 2010.

Asshiddiqie, Jimly, Pengantar Ilmu Hukum Tata Negara, Jakarta, Penerbit Sekretariat Jenderal dan Kepaniteraan Mahkamah Konstitusi Republik Indonesia, 2006.

--------, Teori Hans Kelsen Tentang Hukum, Jakarta, Penerbit Sekretariat Jenderal dan Kepaniteraan Mahkamah Konstitusi Republik Indonesia, 2006.

Basiang, Martin, The Contemporary Law Dictionary, First Edition, Red and White Publishing, 2009.

Bruggink, J.J.H., Refleksi tentang Hukum, Alih Bahasa Arief Sidharta, Bandung, Citra Aditya Bakti, 1999.

Fuller, Lon L. The Morality Of Law, Eight Ways To Fail To Make Law, USA, Yale University Press, 1964.

Hadjon, Philipus. M, et.al., Hukum Administrasi dan Good Governance, Universitas Trisakti, 2010.

--------, Hukum Administrasi Dan Tindak Pidana Korupsi, Gadjah Mada University Press, Yogyakarta 2011.

Marzuki, Peter Mahmud, Pengantar Ilmu Hukum, Jakarta, Kencana Prenada Media Group, 
2009.

Nugraha, Safri, et.al., Hukum Administrasi Negara, Center For Law And GG (GG)Studies CLGS) Depok, Fakultas Hukum Universitas Indonesia, 2007.

Sunaryo, Sidik, Sistem Peradilan Pidana, Malang UMM Press, 2004.

Ragawino, Bega, Hukum Administrasi Negara, Bandung, Universitas Padjadjaran, 2006

\section{Peraturan Perundang-undangan}

Undang-undang Dasar 1945 Amandemen ke-4

Undang-undang Nomor 4 Tahun 2009 Tentang Pertambangan Mineral dan Batubara, Lembaran

Negara Republik Indonesia Nomor 4959, Perubahan Atas Undang-undang Nomor 11

Tahun 1967 Tentang Ketentuan Pokok Pertambangan, Lembaran Negara Tahun 1967

Nomor 22 dan Tambahan Lembaran Negara Nomor 2831

Undang-undang Nomor 1 Tahun 1946 Tentang Kitab Undang-undang Hukum Pidana (KUHP).

Undang-undang Nomor 25 Tahun 2009 Tentang Pelayanan Publik, Lembaran Negara Republik Indonesia Tahun 2009 Nomor 112 dan Tambahan Lembaran Negara Republik Indonesia Nomor 5038.

Undang-undang Nomor 5 Tahun 1986 Tentang Peradilan Tata Usaha Negara sebagaimana diubah dalam Undang-undang Nomor 9 Tahun 2004, Lembaran Negara Republik Indonesia Tahun 2004 Nomor 35 dan Tambahan Lembaran Negara Republik Indonesia Nomor 4380.

Undang-undang Nomor 12 Tahun 2008 Tentang Perubahan Kedua atas Undang-Undang Nomor 32 Tahun 2004 Tentang Pemerintahan Daerah, Lembaran Negara Republik Indonesia Tahun 2008 Nomor 59 dan Tambahan Lembaran Negara Republik Indonesia Nomor 4844.

Undang-undang Nomor 32 Tahun 2004 Tentang Pemerintah Daerah, Lembaran Negara Republik Indonesia Tahun 2004 Nomor 125 dan Tambahan Lembaran Negara Republik Indonesia Nomor 4437.

Undang-undang Nomor 26 Tahun 2007 Tentang Penataan Ruang, Lembaran Negara Republik Indonesia Tahun 2007 Nomor 68 dan Tambahan Lembaran Negara Republik Indonesia Nomor 4725.

Undang-undang Nomor 19 Tahun 2004 Tentang Penetapan Peraturan Pengganti Undangundang Nomor 1 Tahun 2004 tentang Perubahan atas Undang-undang Nomor 41 Tahun 1999 Tentang Kehutanan, Lembaran Negara Republik Indonesia Tahun 2004 Nomor 86 dan Tambahan Lembaran Negara Republik Indonesia Nomor 4412.

Undang-undang Nomor 23 Tahun 1997 Tentang Pengelolaan Lingkungan Hidup, Lembaran Negara Republik Indonesia Tahun 1977 Nomor 68 dan Tambahan Lembaran Negara 
Republik Indonesia Nomor 3699.

Peraturan Pemerintah Republik Indonesia Nomor 38 Tahun 2007 Pembagian Urusan Pemerintahan Antara Pemerintah, Pemerintah Derah Provinsi dan Pemerintah Daerah Kabupaten/Kota, Lembaran Negara Republik Indonesia Tahun 2007 Nomor 82.

Peraturan Pemerintah Republik Indonesia Nomor 75 Tahun 2001 Tentang Perubahan Kedua atas Peraturan Pemerintah Nomor 32 Tahun 1969 Tentang Pelaksanan Undang-undang Nomor 11 Tahun 1967 Tentang Ketentuan-ketentuan Pokok Pertambangan, Lembaran Negara Republik Indonesia Tahun 2001 Nomor 141 dan Tambahan Lembaran Negara Republik Indonesia 4154. 